\title{
Crise no Brasil e impactos na frágil governança regional e federativa da política de saúde
}

\author{
Crisis in Brazil and impacts on the fragile regional and federative \\ health policy governance
}

Alexandre Padilha (https://orcid.org/0000-0002-1934-5450) ${ }^{1}$

Danilo Carvalho Oliveira (https://orcid.org/0000-0003-0258-1577) ${ }^{2}$

Thássia Azevedo Alves (https://orcid.org/0000-0001-9971-4916) ${ }^{3}$

Gastão Wagner de Souza Campos (https://orcid.org/0000-0001-5195-0215) ${ }^{1}$

\footnotetext{
${ }^{1}$ Departamento de Saúde Coletiva, Universidade Estadual de Campinas. Cidade Universitária Zeferino Vaz, Barão Geraldo. 13083-970 Campinas SP Brasil.padilha.alexandre@ gmail.com ${ }^{2}$ Departamento de Medicina Social, Faculdade de Medicina, Universidade de São Paulo. Ribeirão Preto SP Brasil.

${ }^{3}$ Universidade Federal do ABC. São Bernardo do Campo SP Brasil.
}

\begin{abstract}
Since 2014, Brazil has been experiencing an economic-fiscal-political-institutional crisis. This study evaluates whether the implementation of crisis responses contributed to weaken SUS regional and federative governance. This is an implementation study, and two theoretical categories of public health, the power in Testa and the subject in Campos have been incorporated. It presumes that the implementation shifts power and develops subjects. We analyzed public data from 2014 to 2018, organized into four axes of analysis: a) instruments for implementing crisis response; b) parliament and judicial interference in investments; c) legal frameworks of regionalization; d) federative actors and possible defense coalitions. Results show reduced federal resources, specifically for regional care networks; increased parliament and judicial interference with health resources, due to the evolution of congressional amendments and lawsuits, and changes in SUS regionalization guidelines. There is a shift of power from federative regional arrangements to the central government, parliament, the judiciary, and isolated local services. It is concluded that the response to the crisis weakened the regional federative governance of SUS, aggravating the impacts of the crisis on health.

Key words Health systems, Governance, Health policies, Public policies
\end{abstract}




\section{Introduction}

Brazil is experiencing an economic-fiscal-political-institutional crisis. For many authors, this is not a conjunctural crisis. For Pochmann ${ }^{1}$, the world has been going through a crisis of global capitalism since 2008, of which outputs have reorganized it with new centralities in the world economy and labor exploitation, with Brazil included in it. This author addresses the emergence of the "Uberization" of work, synthetically conceptualizing it as the generalization of the forms of employment that the Uber company popularized in transportation: individual autonomy of precarious contracts, 24 -hr availability with long working hours, lack of labor guarantees, nonpre-paid compensation, linked to availability and productivity, bearing labor costs, thus giving rise to a new standard of work and workers' organization. For Pinto ${ }^{2}$, there is a crisis in the Brazilian capitalism at three interdependent dimensions: capitalist accumulation, the political scene, and the relationship between those in political power and the State, particularly represented by the bureaucratic Judiciary-Police system.

For Souza ${ }^{3}$, from another perspective, this is a crisis intoned by the Brazilian elite speech, which blames non-economic strength on State corruption with, turning the State and political elite into a "scapegoat" and criminalizing it. An alliance appears between economic interests and the "intermediate and technical bureaucracies of the State," such as the military in the past and currently with the judiciary. The offensive of the neoliberal agenda at this moment in Brazil, brings us to Bordieau ${ }^{4}$, for whom the current neoliberal revolutions are conservative revolutions, which restore the past, although presenting themselves as progressive.

From the economic point of view, its recessionary milestone begins at the end of 2014, with a negative GDP of $3.8 \%$ in 2015 and $3.6 \%$ in 2016 and a slow recovery of $1 \%$ in 2017 and $1.1 \%$ in 2018. From 2015 to 2018 we had the worst growth period in history. From a fiscal point of view, public deficit starts in 2014, with an average of $1.7 \%$ of fiscal deficit between 2014-2017, with a forecast of $2.1 \%$ of GDP for $2019^{5}$.

From the political point of view, the system and the political parties that have been the leading actors since the redemocratization have been challenged, leading to the interruption of a presidential term and three exchanges of government coalitions from 2015 to $2019^{6}$. From the institu- tional point of view, there has been a fierce power dispute, characterized by Pinto, as mentioned before $^{2}$, as a crisis in the relationship between those in political power and the State, shifting the center of power to sectors of the unelected bureaucracy and the media.

In this context, we assess the SUS regionalization processes. In another article, we retrieved the history and process of regional and federative agreement and cooperation regarding SUS and how it constituted a great challenge ${ }^{7}$. We observe that, although SUS created a set of regional and federative agreement instances and norms, they still have not translated into solid cooperation. In this same article, we point to the lack of political density and the low permeability of regional and federative arrangements to the network, users, workers and external actors. We indicate the need for a combination of stable and potent regional public services and structures that have, on the one hand, the health region as a territorial object, with regional funds, long-term planning and professionals with a regional connection; on the other hand, a governance that is less tied to rigid structures and more in combination between varied public institutions and non-governmental actors, solving common problems and producing subjects.

All of these add up to Campos's problematization regarding the unfinished challenges for the construction of SUS Brazil, about the need to experiment with institutional arrangements to integrate what has been historically fractionated: the fractioning of the continuity of experiences according to the time of government, fractioning of the territories in administrative or federative divisions, fractioning of policies according to the induction, mainly federal, of health programs.

In this article, our goal is to analyze whether the implementation of crisis responses impacted and weakened SUS regional and federative governance. We understand the implementation of responses not as an isolated policy, constructed by an actor, but as a process of negotiation and conflict, having a political subsystem as a unit to be analyzed, based on this concept present in models of implementation studies ${ }^{9}$.

We characterize governance not only as an administrative structure but one including the political-institutional format of the decision-making process, the financing, the scope of the programs, the articulation and cooperation between social and political actors and their arrangements ${ }^{10}$. 


\section{Method}

This is a study that uses the approaches of policy implementation studies, understanding them as a negotiation and conflict process, using the political subsystemas the analysis unit ${ }^{11}$. This comprises exogenous variables, which are socioeconomic conditions and government coalitions, which change over the period. Among the endogenous variables, first, there is an institutional framework, in this case, the Brazilian Universal Health System, SUS, with the rules of health investments, the instances of agreement and decision, responsibilities and competencies of powers and federative entities. Second, the policy implementation instruments, classifying them into informational, regulatory, administrative and financial instruments. Third, the actors who formulate, dispute and mediate the policy implementation with or without defense coalitions. Fourth, the results at the operational level, including possible changes to the original legal framework.

We sought evidence from different data sources, researched for this period from 2014 to 2018: a) analysis of laws, decrees, ordinances, normative manuals and public official documents; $b$ ) minutes, records, public instances and arrangements related to regionalization; c) public positions of representatives and/or entities; d) analysis of technical reports or researches; e) analysis of federal government budget information systems, the Integrated Planning and Budgetary System (SIOP) and Medium and High-Complexity Financial Limits Control System (SISMAC). To gain analytical power, we have established a cut for the state of São Paulo in relation to judicialization and financial incentive aspects.

We determined the following axes of analysis and variables:

a) characterization of the political instruments for the implementation of the crisis response in this subsystem with an impact on the federative regional governance;

b) institutional dispute among the legislative, executive and judiciary powers regarding the guidelines for health investments, based on the evolution of Congressional amendments and the judiciary legal actions;

c) changes in the legal frameworks of regionalization;

d) characterization of federative actors, their profile and positions in relation to regionalization and possible defense coalitions.

The data interpretation and discussion are based on two theoretical references in the field of public health, which we consider as adding analytical capacity to studies of health policy implementation. First, by the understanding of health as a social process by $\mathrm{Testa}^{12}$, where the power category is central, especially in policies and institutional practices. For this author, implementing a health action leads to a shift in power, having characterized the political, technical and administrative power to the reality of health services. Second, an additional perspective brought on by Campos ${ }^{13}$, where health management must consider the political, pedagogical and subjective aspects that permeate the work of health teams, production, power distribution, knowledge circulation and the professionals' objects of investment, their values and culture. In this sense, implementing a policy also means constituting subjects.

\section{Results}

Data will be presented following the four abovementioned analysis axes. Initially, we observed in the characterization of the implementation instruments, in the assessed sources, a sequence of changes in the fiscal legal frameworks, as a financial instrument that constitute the crisis response subsystem.

These changes began with Constitutional Amendment 86/2015, in which Congressional amendments started to have a mandatory budgetary and financial execution; comprising $1.2 \%$ of net current revenue (NCR), which is the current revenue of the previous year, less social security contributions, PIS, and PASEP, of which half is destined to health care.Under the new framework, it is up to the Executive to comply, except in cases where there is a technical impediment, with the same possibility being opened for other federative levels. it also predicted the incorporation of resources from oil and gas to the minimum values to be applied by the Union in health care, changing the pre-salt regulatory framework rule. It also amends the rule that subjected to the complementary law the criteria for sharing health resources with the federative entities.

At a second moment, a New Fiscal Regime established by CA 95/2016 is implemented, which establishes a maximum investment limit for the evolution of federal public investments for 20 years, annually corrected by inflation, leading to the untying of expenses with public health actions and services from the net current revenue; loss of resources in relation to the binding rules 
of Constitutional Amendments n. 29 and n. 86, and the federal governments' release from having to allocate more health resources linked to economic growth. Additionally, the Tripartite Interinstitutional Commission Resolution (CIT) of 10/2016 established that there might be no new investment financing transfer without provisioning for funding.

The researched public sources, reports and Technical Notes from SUS instances and SIOP data revealed that such changes have already affected federal resources for health:

a) there has been a reduction in the percentage related to the NCR of the year, over the years, reaching $13.95 \%$ of the NCR in 2018, with a forecast of $13.9 \%$ in 2019 ; b) both the federal minimum spending ( $R \$ 117.3$ billion) and the budgetary programming ( $\mathrm{R} \$ 117.9$ billion) of expenditures for 2019 on Public Health Services and Actions (Ações e Serviços Públicos de Saúde - ASPS) are lower than the budgetary programming for 2018 (R\$ 119.0 billion); and c) the amounts committed to ASPS in 2018 were approximately $1.9 \%$ higher than in 2017 (R\$ 116.8 billion and R\$ 114.7 billion, respectively), while the 2018 Broad National Consumer Price Index (IPCA) variation was $3.75 \%$.

It is possible that this reduction follows a reduction in transfers to states and municipalities for regional policies.

Graphs 1 and 2, based on public primary data of the transfers to the medium and high-complexity blocks in the state of SP (SISMAC), show how one of the financial political instruments of crisis response implementation was the reduction of transfers to regional care network incentives as of 2015.This reduction directly affects the federative regional governance, as the care network financial incentives were the main federal transfer initiative of Regional Action Plans, built in the Regional Interinstitutional Commissions, involving health regions and integrated pointsof-care.

When we analyze the Graph that includes the set of MAC spending cap resources in the state of São Paulo and the evolution of MAC incentives, we found an upward curve over the period, including resources from healthcare networks, incentives for the hiring of philanthropic and school hospitals, enabling new isolated services. Even with the reduction in the growth velocity, one cannot see the same reduction in the Graph of specific incentives of the regionalized care network. These data reinforce the more intense reduction for the services that constitute the regional care networks, which are priorities established by the federative regional arrangements, different from isolated services. Public reports of the follow-up of regional arrangements, of the coordination for the implementation of the Care Networks in the state of São Paulo, show that a political-administrative instrument for the implementation of the crisis response was the dismantling of the institutional support structure of the Ministry of Health in the territories of the Regional Care Networks.

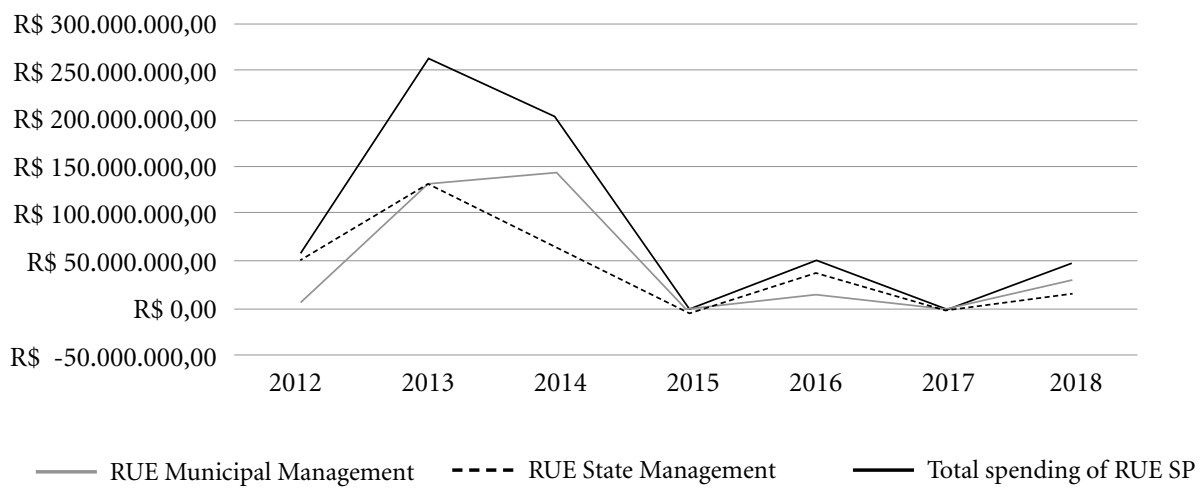

Graph 1. Evolution of the Emergency/Urgency Network (RUE) spending in the State of São Paulo, from 2012 to 2018. 


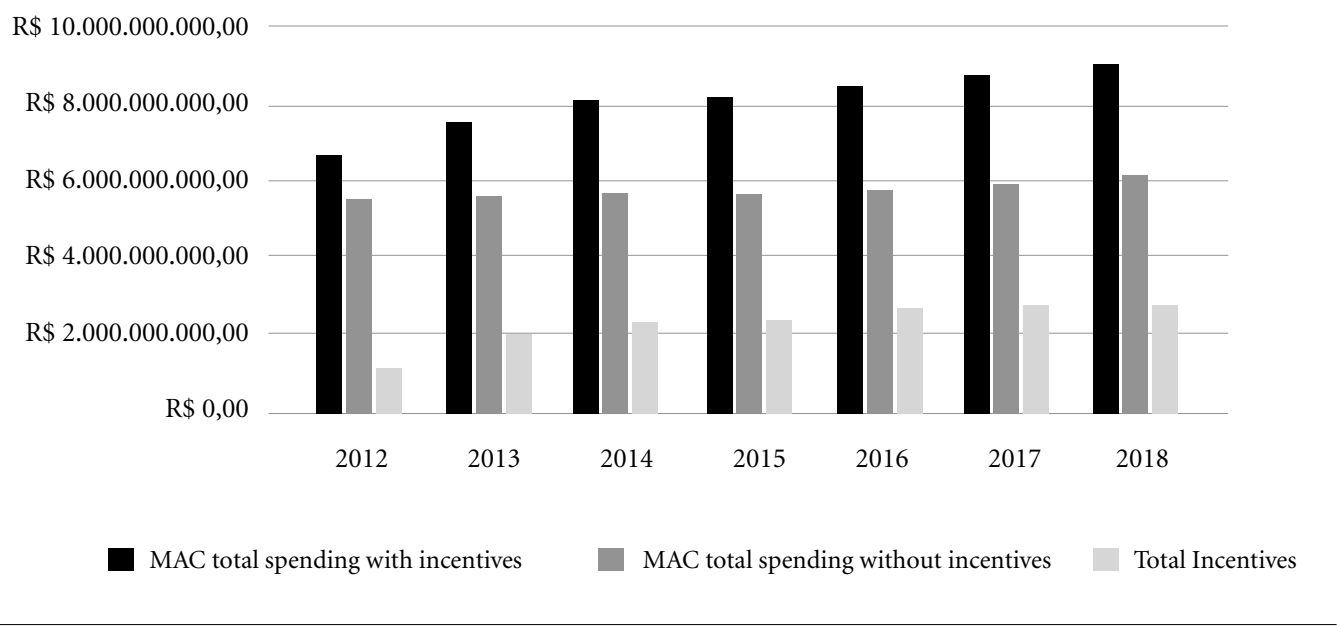

Graph 2. Evolution of the Medium and High-Complexity (MAC)Spending of the State of São Paulo from 2012 to 2018 .

Source: SISMAC v2.0/MS,2019.

These financial and administrative instruments, reducing public investments, as part of the responses createdfor the crisis are characterized by the set of policies called the austerity agenda, as a response in several countries when facing economic instability ${ }^{14}$. These studies show that, in addition to worsening of the population's health and social conditions, there is a delay in the economic recovery. In Brazil, such impacts are worsened by the severe fiscal situation of the states and municipalities ${ }^{15}$, weakening their capacity to expand compensatory actions and those of regional and federative governance.

In the second axis, we sought to disclose evidence of the dispute between the powers of the Republic, as one of the aspects of the institutional crisis and its impacts on the strengthening the federal federative governance of SUS. The Table 1 , with data from SIOPS, depicts the evolution of Congressional amendments on the health budget. There is an increase in absolute and relative terms regarding the committed amount. There is a $160 \%$ increase in the committed amount in Congressional amendments between 2013 and 2018 , compared to a $41 \%$ increase in values committed to the health function. This evolution may have contributed to reduce incentives for regional policies in favor of isolated services. It is not possible to analyze, in this study, whether this evolution also affected the equitable regional distribution of health resources (Table 2).
The data show an exponential increase in the crisis period. In eleven years, from 2008 to 2018, the Federal Government's expenses to comply with court decisions totaled R $\$ 7$ billion, an increase of $1,711 \%$ during the period ${ }^{16}$. This increase possibly originates from a combination of greater judicial activism, with a worsening in the families' income status and interruption of the availability of the medication or service offer. Anyway, these are all aspects of the crisis, looking at it in all its dimensions.

Public data from the regional distribution of legal suits against the State Health Secretariat of São Paulo reinforce the non-equitable aspects regarding health regions, impacting on regional governance. The most demanded health regions in 2017 were, in decreasing order, the municipalities of Barretos, Presidente Prudente, Ribeirão Preto, Marilia, Sao Jose do Rio Preto, although they are not the most populated or most vulnerable. This regional distortion is likely to be even greater according to the federal government data.

An important observation is made by the authors to reflect upon the complex process of judicialization of health. The Brazilian Federal Constitution has provisions that resemble public policies and end up allowing interference by the Judiciary in public policy guidelines. Of the 1,627 provisions, " $30.5 \%$ of them can be safely classified as policy and $69.5 \%$ concern constitutional norms - polity", with policy being related to pub- 
Table 1. Evolution of Congressional amendments and the Health Rubric in the Union Budget.

\begin{tabular}{lccccc}
\hline Year & $\begin{array}{c}\text { Amendment } \\
\text { Authorized }^{*}\end{array}$ & $\begin{array}{c}\text { Amendment } \\
\text { Committed }^{*}\end{array}$ & $\begin{array}{c}\text { Health Budget } \\
\text { Rubrics } \\
\text { authorized }^{*}\end{array}$ & $\begin{array}{c}\text { Health Budget } \\
\text { Rubrics } \\
\text { committed }^{*}\end{array}$ & $\begin{array}{c}\text { Amendment } \\
\text { Committed } \\
\text { Rubrics committed x 100 }\end{array}$ \\
\hline 2012 & 2.20 & 0.65 & 85.4 & 79.91 & 0.8 \\
2103 & 2.16 & 1.08 & 92.29 & 85.3 & 1.2 \\
2014 & 4.47 & 2.89 & 98.03 & 94.06 & 3.0 \\
2015 & 5.02 & 1.5 & 112.79 & 102.09 & 1.4 \\
2016 & 4.75 & 3.8 & 109.86 & 108.26 & 3.5 \\
2017 & 4.82 & 3.9 & 117.16 & 117.60 & 3.3 \\
2018 & 4.85 & 4.7 & 121.63 & 120.87 & 3.8 \\
\hline
\end{tabular}

Source: SIOPS/ *Numbers correspond to values in billions of Brazilian reais $(\mathrm{R} \$)$.

To evaluate the expansion of the protagonism of segments of the Judiciary over the implementation of health policies during the period and the possible impacts on the regional and federative governance of SUS, we assessed the evolution of spending on the judicialization of the Ministry of Health.

Table 2. Ministry of Health judicialization expenses per year.

\begin{tabular}{|c|c|}
\hline Year & Judicialization expenses \\
\hline 2008 & $\mathrm{R} \$ 71.8$ millions \\
\hline 2009 & $\mathrm{R} \$ 106.1$ millions \\
\hline 2010 & $\mathrm{R} \$ 122.6$ millions \\
\hline 2011 & $\mathrm{R} \$ 230.5$ millions \\
\hline 2012 & $\mathrm{R} \$ 367.8$ millions \\
\hline 2013 & $\mathrm{R} \$ 549.1$ millions \\
\hline 2014 & $\mathrm{R} \$ 839.7$ millions \\
\hline 2015 & $\mathrm{R} \$ 1.1$ billion \\
\hline 2016 & $\mathrm{R} \$ 1.3$ billion \\
\hline 2017 & $\mathrm{R} \$ 1.02$ billion \\
\hline 2018 & $\mathrm{R} \$ 1.3$ billion \\
\hline
\end{tabular}

Source: Ministry of Health, 2019.

lic policy and polity meaning what is stable in politics; that is, the rules of the political game"17. This is the case of the right to health, based on the principles of integral, free and universal care.

Thus, if on the one hand, health is considered as a fundamental right of every citizen, on the other hand, the Constitution obliges the state to act to ensure that this right is exercised, opening the possibility of a legal suit to guarantee it.

The judicialization process progresses towards a distortion of responsibilities between federative entities. As observed by Wang et al. ${ }^{18}$, smaller budgets and less developed infrastructure were considered in the distribution of SUS competencies, giving the municipalities attributions related to actions and services of different complexity.

However, the Brazilian Supreme Court (STF) upholds the understanding that the patient can legally claim health goods and services to any entity in the federation. At the court, there is an ongoing proposal to create a binding summary, determining the joint responsibility of the federation entities when the subject is public health, which, for the same author, would be especially costly to the municipalities.

In our view, while the right to health is nonnegotiable, the increased judicialization can result in the following distortions: a) budget deformities that can compromise the collective access to health services and goods, by frequently changing the purchasing planning to meet the demands of a limited number of people; $b$ ) there are decisions that comply with requests for drugs that are not offered by SUS, which do not have scientific evidence about their efficacy and have not even been approved and registered by Anvisa (Brazilian Health Regulatory Agency); c) it increases the asymmetric responsibility between federative entities by determining that the resource should be used to purchase a specialized drug, which is carried out by state or federal entities, and may mean withdrawal of funds from a municipal entity; and d) favors regions that have access to the judiciary regarding a more equitable regional distribution of resources.

Using Testa's categorization of power in health to analyze these data of the evolution on resource allocation, the crisis response triggers a shift of power from regional and federative arrangements to the legislature, judiciary, and federal government. Also within the scope of regional and federative arrangements, this power is shifted from regional collegiate bodies, such as the groups in charge of care networks, to isolated health services, with their internal power centers. They seize the resources, particularly the congressional amendments, to the detriment of care network regional incentives. 
Other studies have previously shown how the growing implementation of Congressional amendments at the federal level increases direct costing investments for isolated health services ${ }^{19}$. The political power of negotiating hospital structures contributes to this shift. Moreover, as a response to the crisis, philanthropic institutions have taken hold of public resources for a new proposal to refinance their debts.(Ministry of Health, Law N. 13,778, of December 26, 2018). The permanent conflict of diverse power structures is one of the characteristics that have been pointed out in the strengthening or fragility of regional and federative governance.

The third axis comprehends the normative changes on federative relations and regionalization, resulting from the process of crisis response implementation. These constitute new regulatory instruments of implementation. The following are highlighted:

Ministerial ordinance GM/MS N. 3.92 of December 28, 2017 and Legal SUS: establishes two blocks of fund-to-fund transfers between the Union, states and municipalities, costing and investment, extinguishing the previous 6 blocks. This is followed by a set of consolidation Ordinances that unifies the transfer criteria ${ }^{20}$;

CIT Resolution N. 23/2017, which establishes rules for the Regional Planning and Care Network Governance process: a) establishes that the Bipartite Intermanagerial Committees (CIB) implement the Executive Governance Committees of the HCNs, with the purpose of monitoring, following, evaluating and proposing solutions for the adequate functioning of the $\mathrm{HCNs}$;

Resolution CIT 37/2018 deals with the process of Integrated Regional Planning and the definition by CIB of the organization of health macro-regions. Implemented and coordinated by the state, it will disclose the responsibilities of health managers and the steps of ascending planning.

We started the last axis, that of the federative actors, with the characterization of the profile of the new municipal managers, who started a new municipal management cycle in 2017. The data obtained from public reports from Conasems show that $56 \%$ were never part of public management, possibly related to the questioning aspect of the crisis political system and high rates of renewal in the municipal elections.

On the strengthening of the Health Management and Regionalization: 56\% indicate the need to strengthen the Regional Interinstitutional Commission (CIR) , 47\% to increase financial re- sources, $46 \%$ to obtain human, technological and financial resources from the State Health Department. As for the main actions to be implemented during the management period (2017-2020) by COSEMs: $49 \%$ must help managers to dialogue with the Control Organs and the Judiciary, to dialogue with State Secretariats (66\%) and the Ministry of Health (73\%).

Aiming to characterize the position of the federative actors that interact in the implementation of these responses to the crisis, we sought to analyze the public positions of their representatives, starting in 2017, due to the new cycle of municipal managers. Chart 1 summarizes the centrality of positions on the federative regional governance and powers.

We consider particularly important, given the historical role that the municipal federative actor has always fulfilled in the construction of SUS, of its regionalization, the public pronouncements of the president of Conasems, transcribed below:

"Financing is the main management enigma, the challenge is to rationalize costs, avoid waste and qualify work, ensuring greater efficiency.... This scenario reinforces what I have told all secretaries and mayors: the manager should not open any new beds in the municipality, since there are no resources for funding ${ }^{21}$."

On regionalization:

"If we do not work in a regionalized manner, do not involve the municipalities in that territory to plan together, sharing responsibilities for regional assistance, we will not be able to move forward. The resources are becoming increasingly scarcer, the demand is getting bigger and the equipment needs to be thought of along with the economy of scale ${ }^{21}$."

An official document from Conasems ${ }^{22}$ on regionalization indicates the following, as the essential attributes of regionalization: a) lower cost; b) financing with equity; c) agreement; d) user as the focus. We emphasize that the lowest cost was listed in the first place.

For Campos, in an aforementioned reference ${ }^{13}$, stimulating the strengthening of subjects, expanding their capacities of analysis and intervention, would be decisive for altering power relations. The responses to the crisis have shaped new subjects that even constitute, in our interpretation, defense coalitions within the characterized political subsystem. One should not confuse these coalitions here with government coalitions, a variable characterized as exogenous to the subsystem, although many of the actors acting within this political subsystem also com- 
Chart 1. Characterization of the federative actors' position in relation to the guidelines of the regional and

\begin{tabular}{|l|l|l|}
\hline \multicolumn{1}{|c|}{ Federative actor } & \multicolumn{1}{|c|}{ Regionalization guideline } & \multicolumn{1}{c|}{$\begin{array}{c}\text { Relationship with the other } \\
\text { Powers }\end{array}$} \\
\hline Ministry of Health & $\begin{array}{l}\text { Evaluate SUS size } \\
\text { Legal SUS: Decrease size, reduce } \\
\text { bureaucratic ordinances } \\
\text { Preponderance of Efficiency Speech }\end{array}$ & $\begin{array}{l}\text { Face judicialization } \\
\text { Alliance with the Legislative for } \\
\text { resources through Congressional } \\
\text { amendments }\end{array}$ \\
\hline State managers & $\begin{array}{l}\text { Defense of Legal SUS } \\
\text { Defense of Care Networks and } \\
\text { Public Consortia for the integrality } \\
\text { and regionalization of } \\
\text { Primary Care as Essential for HCNs }\end{array}$ & $\begin{array}{l}\text { Mobilize governors' involvement in } \\
\text { the Judiciary and Congress }\end{array}$ \\
\hline Conasems (municipal managers) & $\begin{array}{l}\text { Defense of Legal SUS, Ascending } \\
\text { planning Face Judicialization } \\
\text { Defense of Regionalization: } \\
\text { preponderance of efficiency, scale } \\
\text { gain, cost savings in the defense of } \\
\text { regionalization, } \\
\text { diversity and local inequalities }\end{array}$ & \\
\hline
\end{tabular}

Source: Ministry of Health Statements and Public Reports, CONASS and CONASEMs.

prise the government coalitions that were instituted and alternated throughout the crisis.

We identified a defense coalition to reduce the size of the SUS. Irrespective of your beliefs about the universal principle of SUS, in this case the rationality of efficiency operates adaptation strategies in the face of crisis responses. Sometimes it becomes explicit as a result of contingency, as expressed in the words of the president of CONASEMS: "We fought against the setbacks of the CA 95. Now, after the defeat, what remains is to gain efficiency." The federal government leads it, since the interruption of the government of President Dilma. This rationality is at the heart of the defense made by the national association of municipal managers on the regionalization of SUS.

For this coalition, the regionalization guidelines are aligned with agility, the decrease in bureaucracy, flexibility, scale gain, flexibility to adapt to the local reality. Although in rhetoric they interact with the debate about a model of care guided by a person-centered primary care, we have not identified any new concrete measures to uphold this model of care as a response to the crisis.

Other subjects interact in this subsystem, in what we will call the punctual survival of rights, given the scenario of asphyxiation of resources and reduced governability of the executive, seeking to preserve or enable certain rights and interests. We include here the segments that stimulate the judicialization, strengthened by the shift of power to this segment, triggered by the crisis itself. From another perspective, the federal parliament and the interests they represent also express themselves, taking advantage of this moment of reduced governability of the Executive to seize part of the federal resources destined to SUS. Possibly other actors, which were not the object of analysis in the present study, comprise this perspective: private actors from the service, industry and care complex; family associations, philanthropic hospitals.

\section{Conclusion}

The implementation of the responses to the crisis, developed within the characterized subsystem, weakened the federative regional governance of SUS. This impact is likely to be unequal in Brazil, as our regional and federative structure is absolutely unequal and asymmetrical, particularly in SUS.

From the point of view of implementation instruments, our study shows that the federal agenda negotiated with other federative actors used financial, administrative and regulatory instruments that emptied the regional and feder- 
ative governance policies. Responses from other actors, notably the Judiciary and the Congress, also had a negative impact.

This combination of responses, resulting from the ongoing process of negotiation, conflict and learning, characteristic of the implementation study approaches, reveals the contribution of the policy subsystem model used. It allowed a broader view of the process of implementation of ongoing responses, as it can identify the impacts of seemingly disconnected strategies that merge and explain the impact on regional and federative governance.

This analysis unit allowed us not to be restricted to the economic and fiscal aspects of the crisis, encompassing aspects of legal frameworks, formulation and agreement instances, and actors who express their point of view, dispute and negotiate. In this sense, the results obtained in the analysis of the four chosen axes are joined, disclosing that the impacts related to the financial and administrative instruments that implemented the response to the crisis in the federative regional governance are broadened, as the other powers, namely the Legislative and Judiciary, implementing responses that extend their interference in resource allocation, and federative actors that constitute a coalition of defense that survives resource constraints by changing legal marks of regionalization. Combined variables increase the weakening of the federative regional governance mechanisms.

The regional and federative governance of SUS, which could be an important resource, even to counterbalance such crisis responses or to at- tenuate the impact on the population health, discloses the interdependence of federal initiatives, although further studies are needed on the impacts on federative regional arrangements in the period to better measure the distribution of such impacts and singularities of each region.

When analyzing the results from the theoretical references of Testa and Campos, we observe that the implementation of the crisis response led at the federal level produced a shift in power from the regional and federative arrangements to the several institutional political actors. The implementation process contributed to the configuration or strengthening of new subjects, some of them constituting certain decisive defense coalitions.

From the perspectives mentioned herein, of Campos and Testa, such coalitions assert themselves as new subjects that have an impact on SUS and its regional and federative governance, representing shifts in technical, political and administrative power. Studies that accompany the characterized coalitions and analyze the implementation of the new regulatory guidelines for regionalization, the result of conflict and negotiation of crisis response, will be important for further analysis.

In this study, it was not possible to evaluate the implementation of the Executive Governance Committees of the HCNs, a result of the new identified norms. However, due to their conception and composition, they may suffer from what we observed in a previously mentioned study: low political density in its construction, low permeability to the set of actors that comprise the HCNs.

\section{Collaborations}

A Padilha: participated in the study conception, design, analysis and interpretation of data, writing and approval of the final version of the manuscript. DC Oliveira: participated in the study conception, design, analysis and interpretation of the data, writing and approval of the final version of the manuscript. TA Alves: participated in the study conception, design, analysis and partial interpretation of the data, writing and approval of the final version of the manuscript. GWS Campos: participated in the study conception and design of the analysis. 


\section{Referências}

1. Pochmann M. A crise capitalista e os desafios dos trabalhadores. Cadernos do CEAS 2017; 239:698-712.

2. Pinto E, Pinto JPG, Saludjian A, Nogueira I, Balanco P, Schonerwald C, Baruco G. A Guerra de Todos contra Todos: A Crise Brasileira. Rio de Janeiro: IE/UFRJ; 2017. [texto para discussão 006]. [acessado $2017 \mathrm{dez}$ 18]. Disponível em: http://www.ie.ufrj.br/index.php/ index-publicacoes/textos-para-discussão

3. Souza J. A elite do atraso: Da escravidão à Lava-Jato. Rio de Janeiro: Leya; 2017.

4. Bourdieu P. Uma revolução conservadora. Política \& Sociedade 2018; 17(39).

5. Carvalho L. Valsa Brasileira Do Boom ao Caos Econômico. São Paulo: Todavia; 2018.

6. Singer A. O Lulismo em Crise. São Paulo: Companhia das Letras; 2017.

7. Padilha A, Amaral MA, Oliveira D, Campos GWS. Fragilidade na governança regional durante implementação da Rede de Urgência e Emergência em Região Metropolitana. Saúde Debate 2018; 42(118):579-593.

8. Campos GWS. Regionalização é o futuro do SUS [internet]. Brasília: Região e Redes; 2014. [acessado 2017 Dez 18]. Disponível em: http://www.resbr.net.br/regionalizacao-e-o-futuro-do-sus/

9. Sabatier PA, Jenkins-Smith HC. The Advocacy Coalition Framework: An Assessment. In: Sabatier PA, editor. Theories of the Policy Process. Boulder: Westview Policy Analysis and Management; 1999. p. 226-245

10. Melo RS, Batista PCS, Macedo ACM, Costa RBL. Governança corporativa, criação de Valor e desempenho econômico-financeiro: evidências do mercado brasileiro com dados em painel, 2005-2011. Rege 2013; 20(1):79-92.

11. Howlett M, Ramesh M, Perl A. Política Pública: seus ciclos e subsistemas - uma abordagem integradora. Rio de Janeiro: Elsevier; 2013.

12. Testa M. Pensar em Saúde. Porto Alegre: Artes Medicas; 1992.

13. Campos GWS. Um método para análise e co-gestão de coletivos. $3^{\mathrm{a}}$ ed. São Paulo: Hucitec; 2007.

14. Vieira FS. Crise econômica, austeridade fiscal e saúde: que lições podem ser aprendidas? Brasília: IPEA; 2016. [NT no 26]

15. Mercês G, Freire N. Crise fiscal dos estados e o caso do Rio de Janeiro. Geo UERJ 2017; 31:64-80.
16. Brasil. Ministério da Saúde (MS). Dados públicos apresentados em instâncias de pactuação. Brasília: MS; 2019.

17. Couto C, Arantes R. Constituição, Governo e Democracia no Brasil. RBCS 2006; 21(61):41-62.

18. Wang DWL, Vasconcelos NP, Oliveira VE, Terrazas FV. Os impactos da judicialização da saúde no município de São Paulo: gasto público e organização federativa. Rev. Adm. Pública 2014; 48(5):1191-1206.

19. Turino F, Sodré F. Organizações sociais de saúde financiadas por emendas parlamentares. Trab Educ Saude 2018; 16(3):1201-1219.

20. Brasil. Ministério da Saúde (MS). Portaria GM/MS nº 3.992, de 28 de dezembro de 2017. Altera a Portaria de Consolidação no 6/GM/MS, de 28 de setembro de 2017, para dispor sobre o financiamento e a transferência dos recursos federais para as ações e os serviços públicos de saúde do Sistema Único de Saúde. Diário Oficial da União 2017; 28 set.

21. Conselho Nacional de Secretarias Nacionais de Saúde (CONASEMS). Entrevista com Mauro Junqueira. Brasília: CONASEMS; 2016. [Revista do CONASEMS 67]

22. Conselho Nacional de Secretarias Nacionais de Saúde (CONASEMS). Saúde e Regionalização da Saúde e Posicionamentos e Orientações. Brasília: CONASEMS; 2019.

Article submitted on 03/20/2019

Approved on 07/12/2019

Final version submitted on 08/29/2019 